FEATURE

Alex Turvey, Jonathan Knight

Office for National Statistics

Birgit Wosnitza

Department of Energy and Climate Change (formerly Office for National Statistics)

\title{
Regional economic indicators A focus on household income
}

\section{Focus on household income}

his article focuses on regional gross disposable household income (GDHI), a key determinant of welfare, which can be described as the general well-being and prosperity of the residents living in a region. GDHI represents the amount of money available to households after taxes, National Insurance and pension contributions, property costs and other interest payments have been deducted. To allow comparisons across regions, household income per head of the resident population is used.

On 2 April 2009 new GDHI estimates were published up to 2007 . The data include substantial revisions throughout the time series as a result of methodological changes made to ensure consistency with Blue Book 2008 , most notably the reallocation of financial intermediation services indirectly measured from intermediate to final consumption and apportionment across regions. The estimates are at current basic prices and so do not take inflation effects or regional price differences into account. Table 1 presents figures for GDHI per head from 2000 to 2007 in each of the 12 UK regions, as well as the average for the UK as a whole.

Table 1 shows that, over the time period studied, London has consistently had the highest GDHI per head, and the average annual growth rate of the region is above the UK average, implying a divergence between the performance of London and the other regions of the UK. This result ties in with London's strong performance in terms of GVA per head and productivity growth so far this century.

GDHI per head is next highest in the South East and the East of England, the regions which together with London comprise the 'Greater South East'. These regions benefit from their proximity to the capital, with high value-added businesses locating nearby and workers commuting to highly-paid jobs in London. However, the two regions experienced the lowest growth in household income between 2000 and 2007.

The strongest growth in household income occurred in Northern Ireland. Household income in the region grew at an average of 4.2 per cent per annum, overtaking the North East, which despite also having a growth rate above the UK average, has fallen to the bottom of the ranking of GDHI per head. Growth in GDHI per head was also strong in Wales, Scotland and the East Midlands, enabling some convergence between these regions and the UK average.

Focusing on the most recent data, Figure 1 shows the difference in percentage points from the UK average of regional GDHI per head in 2007. As could be seen in Table 1, only those regions in the 'Greater South East' had GDHI per head values above the UK average - by 25 per cent in London, 12 per cent in the South East and 5 per cent in the East of England. Of those regions with GDHI per head below the UK average, the divergence ranged from 1 per cent in the South West to 15 per cent in the North East. 
Table 1

Headline gross disposable household income per head at current basic prices: by NUTS1 region

$£$ per head and percentages

\begin{tabular}{|c|c|c|c|c|c|c|c|c|c|c|c|c|c|c|}
\hline & & & & Yorkshire & & & & & & & & & & \\
\hline & $\begin{array}{r}\text { United } \\
\text { Kingdom }^{1}\end{array}$ & $\begin{array}{r}\text { North } \\
\text { East }\end{array}$ & $\begin{array}{r}\text { North } \\
\text { West }\end{array}$ & $\begin{array}{l}\text { and The } \\
\text { Humber }\end{array}$ & $\begin{array}{r}\text { East } \\
\text { Midlands }\end{array}$ & $\begin{array}{r}\text { West } \\
\text { Midlands }\end{array}$ & $\begin{array}{l}\text { East of } \\
\text { England }\end{array}$ & London & $\begin{array}{r}\text { South } \\
\text { East }\end{array}$ & $\begin{array}{r}\text { South } \\
\text { West }\end{array}$ & England & Wales & Scotland & $\begin{array}{r}\text { Northern } \\
\text { Ireland }\end{array}$ \\
\hline 2000 & 11,146 & 9,440 & 10,164 & 10,132 & 10,184 & 10,165 & 11,946 & 13,757 & 12,863 & 11,077 & 11,377 & 9,583 & 10,381 & 9,382 \\
\hline 2001 & 11,827 & 9,979 & 10,746 & 10,685 & 10,848 & 10,752 & 12,760 & 14,559 & 13,670 & 11,770 & 12,071 & 10,211 & 11,003 & 9,934 \\
\hline 2002 & 12,209 & 10,348 & 11,096 & 10,995 & 11,245 & 11,091 & 13,177 & 14,999 & 14,013 & 12,151 & 12,445 & 10,674 & 11,419 & 10,299 \\
\hline 2003 & 12,759 & 10,832 & 11,576 & 11,501 & 11,804 & 11,584 & 13,720 & 15,712 & 14,571 & 12,685 & 12,994 & 11,144 & 12,002 & 10,896 \\
\hline 2004 & 13,005 & 11,069 & 11,799 & 11,749 & 12,083 & 11,785 & 13,910 & 16,108 & 14,744 & 12,925 & 13,238 & 11,396 & 12,258 & 11,181 \\
\hline 2005 & 13,611 & 11,590 & 12,339 & 12,273 & 12,668 & 12,288 & 14,453 & 16,951 & 15,388 & 13,527 & 13,846 & 11,939 & 12,871 & 11,787 \\
\hline 2006 & 14,053 & 12,026 & 12,778 & 12,660 & 13,032 & 12,697 & 14,855 & 17,512 & 15,821 & 13,968 & 14,285 & 12,366 & 13,347 & 12,234 \\
\hline $2007^{2}$ & 14,317 & 12,216 & 13,038 & 12,901 & 13,268 & 12,941 & 15,083 & 17,931 & 16,095 & 14,187 & 14,556 & 12,574 & 13,587 & 12,472 \\
\hline $\begin{array}{l}\text { Average annual percentage } \\
\text { growth, } 2000-2007^{2}\end{array}$ & 3.6 & 3.8 & 3.6 & 3.5 & 3.9 & 3.5 & 3.4 & 3.9 & 3.3 & 3.6 & 3.6 & 4.0 & 3.9 & 4.2 \\
\hline
\end{tabular}

Notes:

1 UK less Extra-regio.

2 Provisional.

Figure 1

\section{Headline gross disposable household income per head: by NUTS1 region, $2007^{1}$}

Percentage difference from the UK average

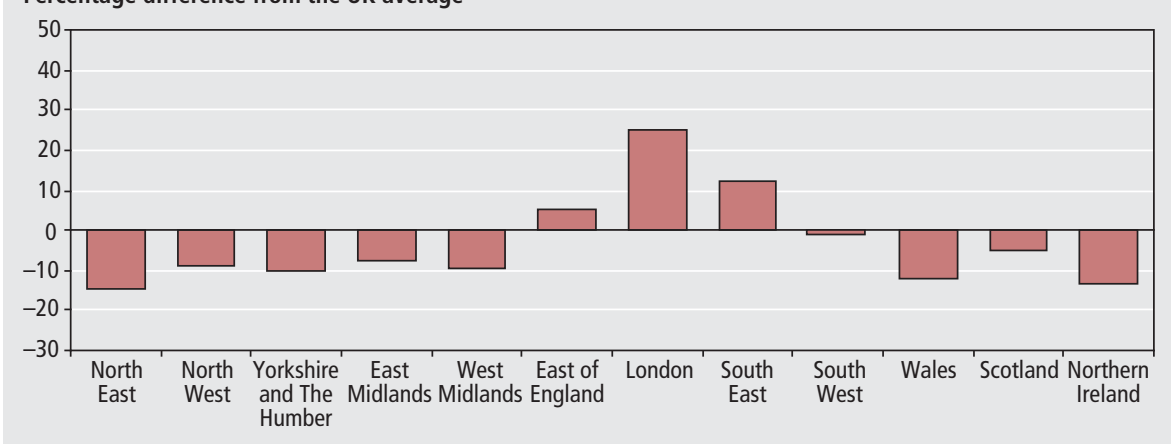

\section{Note:}

Source: Office for National Statistics

1 Provisional.

\section{Figure 2}

\section{Headline gross disposable household income per head and components, by NUTS1 region, $2007^{1}$}

$\mathrm{f}$ per head (thousands)

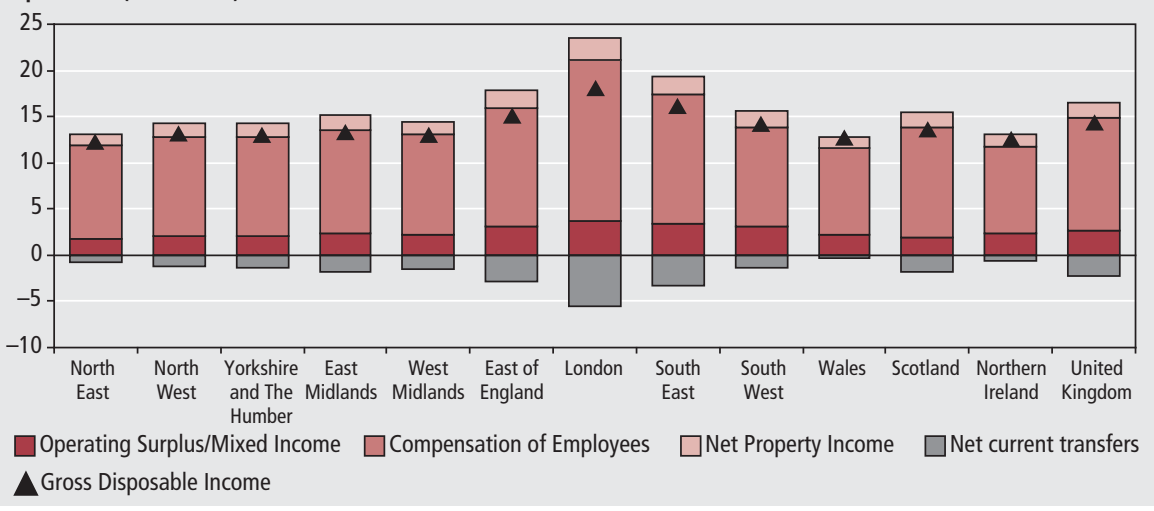

Note:

1 Provisional.

Source: Office for National Statistics

To better understand what is driving differences in GDHI per head, it is necessary to investigate regional performance in terms of the components of household income. GDHI can be split into the following components, all of
Source: Regional Accounts, Office for National Statistics

comprises wages and salaries plus employers' social contributions, typically in the form of pension or health benefits

- operating surplus and mixed income, the former being a mixture of actual rental from housing and imputed rental of owner-occupiers, the latter representing the income of the selfemployed

- net property income, equal to property income received (in the form of interest, rent on land, dividends or other income distributed from companies) less interest and rent on land paid out

- net current transfers: equivalent to the 'balance of secondary income per head' described in Holmes

(2008), this consists of social benefits less social contributions (such as National Insurance and pensions) and other current transfers less taxes on income and wealth. In essence, this represents the redistribution of 'primary income, which is the sum of the three components above. Due to its construction, this term will be routinely negative (it captures virtually all of the contributions to public services by accounting for current taxes, but not all of the benefits received as it does not include the value of services such as health and education provision), but its magnitude is of particular interest in analysing the extent of the redistribution of income across regions

Figure 2 presents a breakdown of regional GDHI per head in 2007 into the shares of these four components. As can be seen, CoE per head is the principal contributor 
Table 2

Headline gross disposable household income per head and components, by NUTS2 area, $2007^{1}$

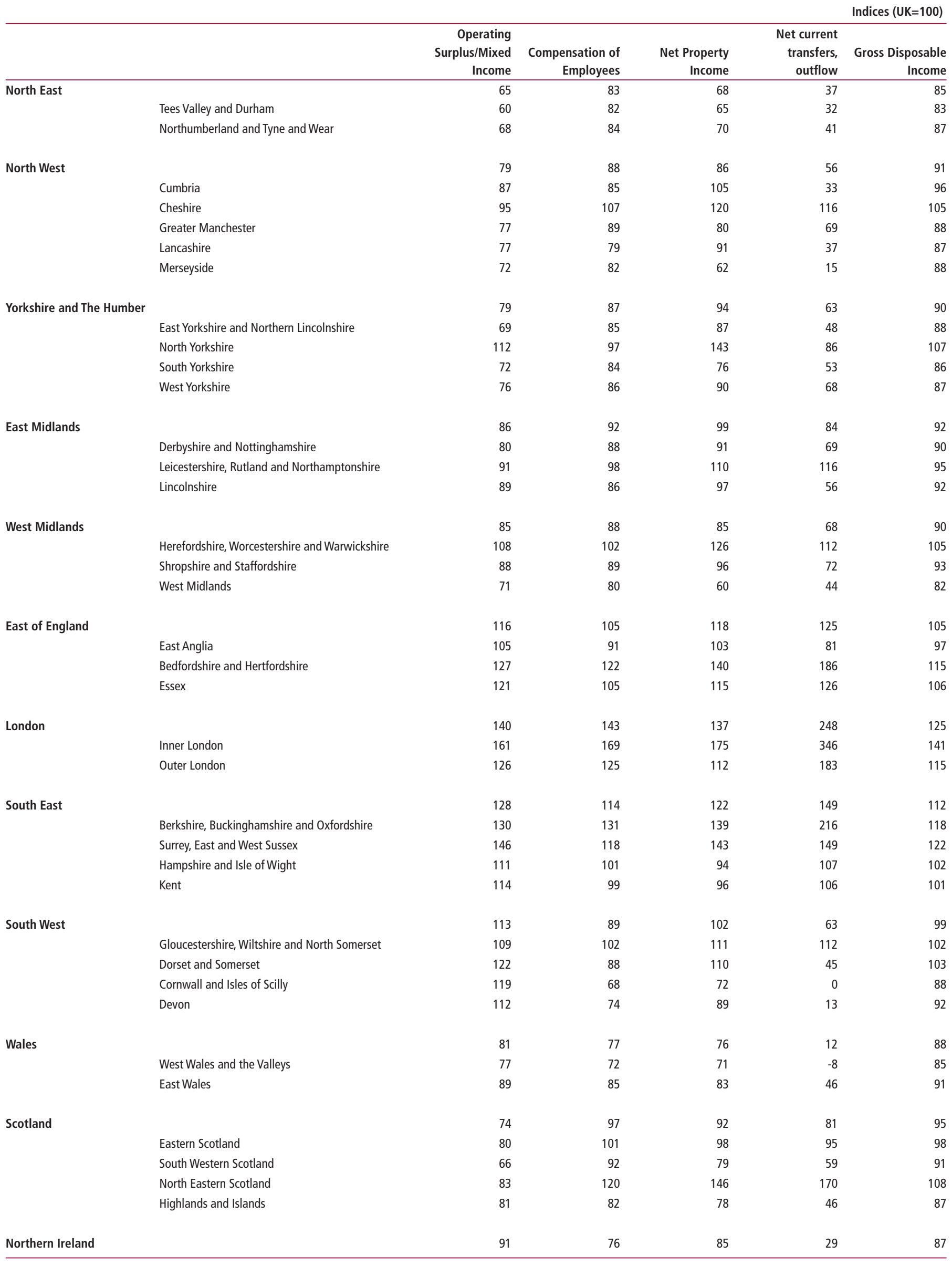


to household income in every region, accounting for approximately three quarters of primary income; it follows that the regions with the largest CoE per head London, the South East and the East of England - also have the largest GDHI per head. A similar pattern occurs with the combined operating surplus/mixed income and net property income components, which likely reflects the higher house prices, share ownership and financial wealth in the 'Greater South East' compared with the rest of the UK.

Net current transfers subtract from primary income in all regions, but these deductions are greatest for those regions with the highest GDHI per head - approximately one quarter of primary income is redistributed from London, compared with a UK average of 13 per cent. This result is to be expected given the progressive nature of the UK tax system and the fact that demand for the social benefits included in this indicator (such as unemployment and housing benefit) is likely to be lower in areas with relatively higher incomes.

However, the regional GDHI breakdown presented in Figure 2 masks a great deal of variation within regions. Trends in these sub-regions drive regional GDHI; thus, an understanding of sub-regional performance is crucial in explaining higherlevel phenomena. Table 2 presents indices $(\mathrm{UK}=100)$ of GDHI and its components by NUTS2 sub-region. It is important to note that in the context of an index, the 'net current transfers' term represents an outflow of income from an area, due to the UK average also being a net outward transfer, hence a larger index number represents a greater redistribution of income away from that particular area.

Interesting points to note from Table 2 are:

- in general, the spread of GDHI per head across sub-regions is much smaller than the spread of individual components, underscoring the fact that some redistribution is taking place

- Inner London is the sub-region which is principally driving the strong performance of the wider London region. The area leads the UK in all components of GDHI per head, and consequently also redistributes more income than anywhere else (almost three and a half times the UK average), although Outer London still has amongst the highest GDHI per head in the country
- compensation of employees per head tends to be above average in those sub-regions which comprise the 'Greater South East', and below average elsewhere. Similarly, operating surplus and mixed income tend to be highest in areas with particularly buoyant housing markets up to 2007 , which additionally includes the sub-regions of the South West

- GDHI and its components are also above average in Cheshire and Herefordshire, Worcestershire and Warwickshire, which serve as important commuter areas for the major regional cities of Manchester, Liverpool and Birmingham

- the strong performance of North Eastern Scotland in terms of CoE and net property income per head. The sub-region includes the cluster of oil and gas-related activities based in and around Aberdeen, which provide highwage jobs and distributed profits from local partnerships, especially in times of high oil prices

- the negative figure for net outward transfers in West Wales and the Valleys means that the sub-region is actually a net recipient of secondary income, which accords with the area having the lowest $\mathrm{CoE}$ and net property income per head in the UK. Similarly, the zero figure for Cornwall and the Isles of Scilly implies a negligible outward transfer from the area

\section{Regional overview}

Key figures on a regional basis indicate that:

- in 2007 London was the region with the highest productivity, in terms of GVA per hour worked, at 30 percentage points above the UK average. Northern Ireland had the lowest productivity in 2007 , at 16 percentage points below the UK average

- between 2007 and 2008, the statistical value of exports grew by approximately 12 per cent in the UK as a whole. Growth was highest in the South East and Wales, at 19 per cent, and lowest in Scotland, at 4 per cent

- the South East had the highest employment rate in the fourth quarter of 2008, at 79 per cent; Northern Ireland had the lowest rate, at 69 per cent, compared with a UK average of 74 per cent

- in the fourth quarter of 2008 , the unemployment rate was highest in the North East (8.4 per cent) and lowest in the South West (4.7 per cent). The unemployment rate increased in all regions over the year to the fourth quarter of 2008

\section{Headline indicators}

In order to gain an overview of the economic performance of UK regions, this article discusses a selection of economic indicators. Currently, the most widely used indicator of regional economic performance is Gross Value Added (GVA) per head. Policymakers frequently use GVA per head as a headline indicator of regional productivity and regional incomes when comparing and benchmarking regions that differ in geographical size, economic output and population. However, as Dunnell (2009) has explained, productivity and income are very different concepts.

GVA per head is calculated as the simple ratio of the economic activity in a region divided by the number of people living in a region, while productivity is defined as the ratio of GVA divided by the labour input (jobs or hours worked) used to create it. GVA per head does not take account of:

- people commuting in and out of regions to work

- regional differences in the percentages of residents who are not directly contributing to GVA, such as young people or pensioners, and

- different labour market structures across regions, such as full- and parttime working arrangements

Therefore, GVA per hour worked or GVA per filled job are more appropriate productivity indicators.

Similarly, Gross Disposable Household Income (GDHI) per head is a better measure of regional incomes than GVA per head. For example, due to commuting, residents might derive their incomes from economic activity in another region, which is not captured by GVA per head of their region. They may also have sources of income which are unrelated to current work, such as pensions and investment incomes.

\section{Regional performance}

GVA is a good measure of the economic output of a region. In December 2008, ONS published new GVA estimates for 2007 and revised estimates for previous years. Table 3 shows the regional economic performance in terms of workplacebased GVA and GVA per head and their 
Table 3

Workplace-based gross value added and gross value added per head at current basic prices: by NUTS1 region

\begin{tabular}{|c|c|c|c|c|c|c|c|c|c|c|c|c|c|}
\hline & & & & Yorkshire & & & & & & & & & \\
\hline & UK $^{1}$ & $\begin{array}{r}\text { North } \\
\text { East }\end{array}$ & $\begin{array}{r}\text { North } \\
\text { West }\end{array}$ & $\begin{array}{l}\text { and The } \\
\text { Humber }\end{array}$ & $\begin{array}{r}\text { East } \\
\text { Midlands }\end{array}$ & $\begin{array}{r}\text { West } \\
\text { Midlands }\end{array}$ & $\begin{array}{l}\text { East of } \\
\text { England }\end{array}$ & London & $\begin{array}{r}\text { South } \\
\text { East }\end{array}$ & $\begin{array}{r}\text { South } \\
\text { West }\end{array}$ & Wales & Scotland & $\begin{array}{r}\text { Northern } \\
\text { Ireland }\end{array}$ \\
\hline \multicolumn{14}{|l|}{ GVA (f million) } \\
\hline 2000 & 842,542 & 28,282 & 84,683 & 61,461 & 52,590 & 68,394 & 72,332 & 168,976 & 123,283 & 64,204 & 31,686 & 67,194 & 19,458 \\
\hline $2007^{2}$ & $1,216,835$ & 40,277 & 120,520 & 87,235 & 78,068 & 92,165 & 107,005 & 250,148 & 175,303 & 94,152 & 44,308 & 98,877 & 28,781 \\
\hline $\begin{array}{l}\text { Average annual percentage growth } \\
2000-2007^{2}\end{array}$ & 5.4 & 5.2 & 5.2 & 5.1 & 5.8 & 4.4 & 5.8 & 5.8 & 5.2 & 5.6 & 4.9 & 5.7 & 5.8 \\
\hline \multicolumn{14}{|l|}{ GVA per head (f) } \\
\hline 2000 & 14,308 & 11,120 & 12,501 & 12,395 & 12,617 & 12,979 & 13,457 & 23,350 & 15,429 & 13,057 & 10,900 & 13,272 & 11,562 \\
\hline $2007^{2}$ & 19,956 & 15,706 & 17,558 & 16,850 & 17,744 & 17,125 & 18,902 & 33,102 & 21,099 & 18,183 & 14,869 & 19,221 & 16,361 \\
\hline $\begin{array}{l}\text { Average annual percentage growth } \\
2000-2007^{2}\end{array}$ & 4.9 & 5.1 & 5.0 & 4.5 & 5.0 & 4.0 & 5.0 & 5.1 & 4.6 & 4.8 & 4.5 & 5.4 & 5.1 \\
\hline
\end{tabular}

Notes:

1 UK less Extra-regio and statistical discrepancy.

2 Provisional. respective average annual growth over the period 2000 to 2007. Although GVA per head is not a good indicator of regional productivity or income, it does take account of variations in geographical size among UK regions and therefore allows better comparisons.

The estimates show that London had the highest GVA ( $£ 250$ billion) and GVA per head $(£ 33,102)$ in 2007 , followed by the South East ( $£ 175$ billion and $£ 21,099$, respectively). The North West generated the third highest GVA ( $£ 121$ billion), but was seventh in terms of its GVA per head $(£ 17,558)$. Northern Ireland and the North East had the lowest GVA in 2007, while Wales and the North East had the lowest GVA per head.

In terms of average annual percentage growth of GVA between 2000 and 2007, the East Midlands, London, Northern Ireland and the East of England had the highest GVA growth, while the West Midlands and Wales had the lowest. Average annual percentage growth of GVA per head was highest in Scotland, London, Northern Ireland and the North East, while the West Midlands, Yorkshire and The Humber and Wales grew slowest.

\section{Labour productivity}

To compare regions in terms of productivity, GVA per hour worked is the preferred indicator. At lower levels of geography, 'hours worked' estimates are not yet available and GVA per filled job should be used. These two measures of productivity divide GVA by the labour input, namely hours worked in all jobs or the number of jobs, used to create it.

GVA per hour worked and GVA per filled job take account of commuting effects and different age profiles, and the former also accounts for variations in labour market structures, such as full- and parttime working arrangements and job share availability.

On 11 February 2009, new productivity estimates for 2007 and revised estimates for previous years were published. These estimates make use of the new and revised GVA figures, which are presented in Table 3 , and updated 'filled jobs' and 'hours worked' estimates.

It should be noted that the productivity figures presented here use unsmoothed GVA as their output measure as opposed to headline GVA, which is calculated as a five-year moving average. The unsmoothed measure is used to ensure consistency with the labour input data (Dey-Chowdhury et al 2008), but raises some concerns about increased volatility of productivity estimates compared to those based on headline GVA. The question of whether to smooth productivity figures after dividing unsmoothed GVA by labour data, and present these as headline estimates, is one which will be addressed by ONS in the coming months.

Figure 3 shows that in 2007 GVA per filled job and GVA per hour worked exhibited smaller differences from the UK average than the catch-all indicator GVA per head. This is mainly due to commuting patterns. London, for example, has a very high GVA per head, mainly due to incoming workers generating a high GVA, which is then divided by a much lower resident population. Productivity indicators, on the other hand, divide regional GVA by the jobs or hours worked to create it.

Figure $\mathbf{4}$ shows the regional GVA per hour worked productivity index on a time series basis from 2001 to 2007. In 2007, London, the South East and the East of England were the only three regions with a productivity performance above the UK average. The East of England saw the strongest improvement in its relative performance between 2001 and 2007, from below the UK average to above average in

\section{Figure 3}

\section{Comparison of regional economic indicators: by NUTS1 region}

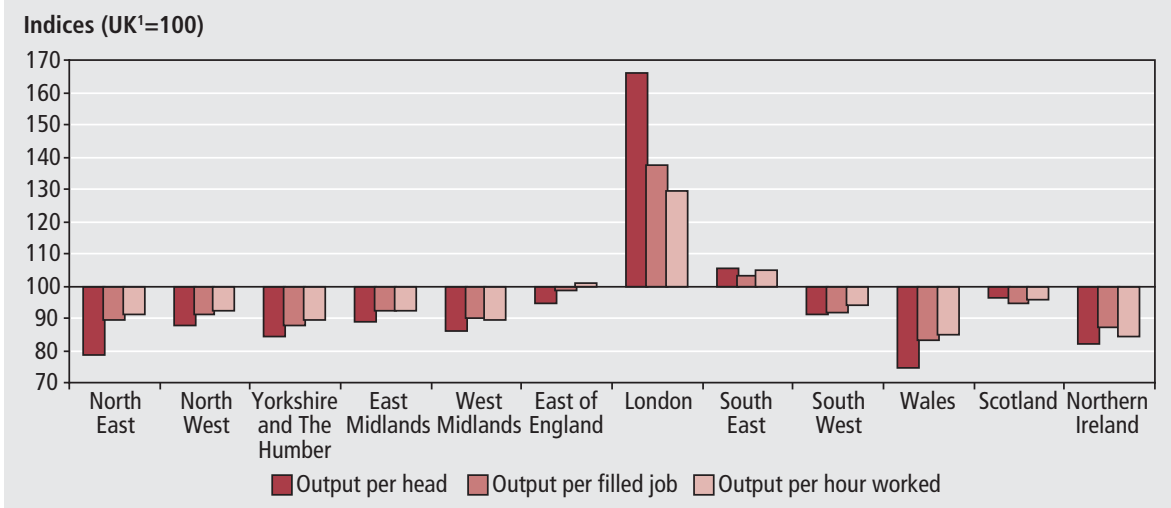

1 UK less Extra-regio and statistical discrepancy. 


\section{Figure 4}

\section{GVA per hour worked: by NUTS1 region}

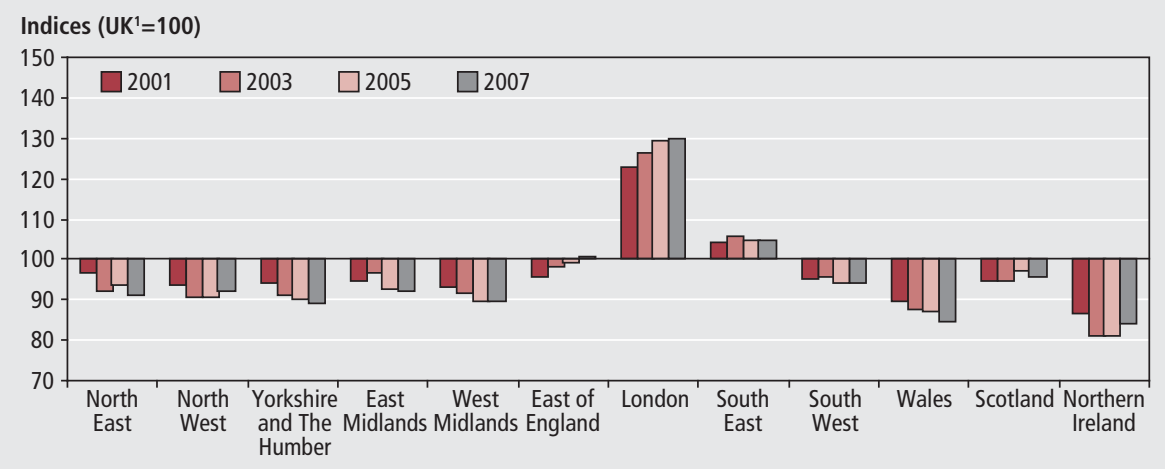

Note:

Source: Office for National Statistics

1 UK less Extra-regio and statistical discrepancy.

\section{Figure 5}

Headline gross disposable household income per head: by NUTS1 region

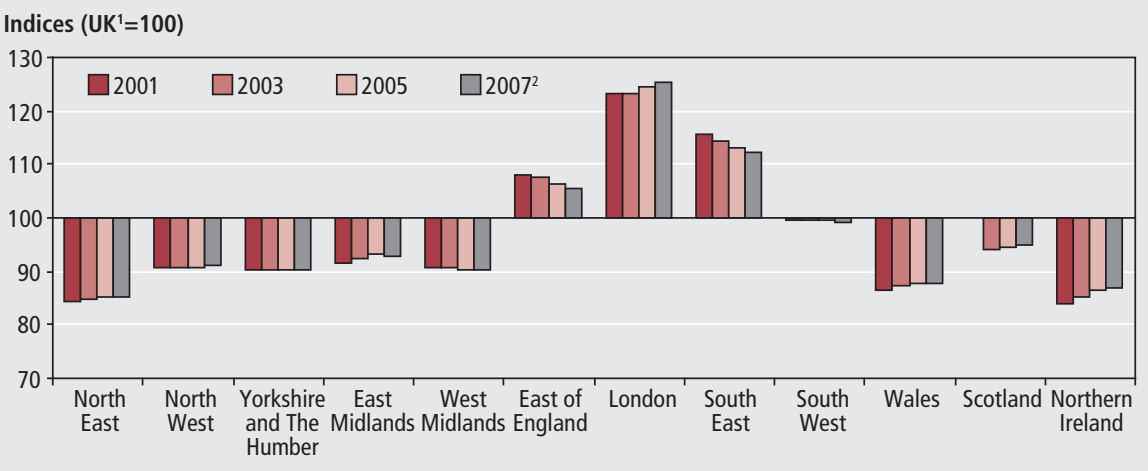

\section{Notes:}

Source: Office for National Statistics

1 UK less Extra-regio.

2 Provisional.

\section{Figure 6}

Gross median weekly pay of all full-time employees: by NUTS1 region, April 2008

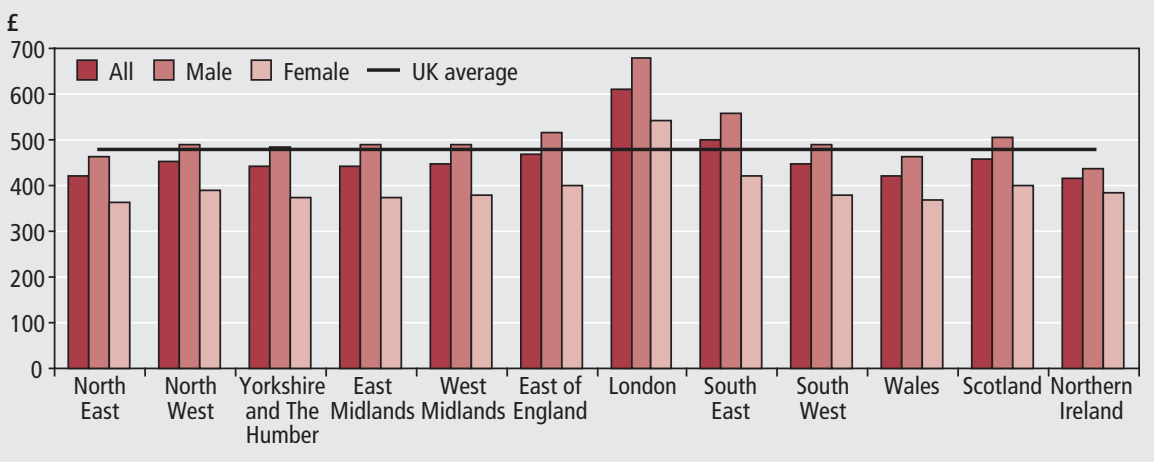

Source: Annual Survey of Hours and Earnings, Office for National Statistics

2007. London also improved its relative performance, therefore diverging further from the UK average. Northern Ireland and Wales had the lowest productivity in 2007. The strongest divergence from the UK average between 2001 and 2007 was experienced in the North East, Wales and Yorkshire and The Humber. This implies that these regions' productivity grew by less than the UK average, therefore widening the productivity gap between regions.

\section{Income of residents}

The focus section has investigated GDHI and the contribution of its components. Figure 5 presents indices of GDHI per head for 2001, 2003, 2005 and 2007 showing movements in regional household income relative to the UK average over time. Figure 5 reaffirms the trends outlined in Table 1, with GDHI per head highest, and diverging from the national average, in London; the South East and East of England being the only other regions with household income above average, but getting closer to it; and the two regions with the lowest GDHI per head (Northern Ireland and the North East) experiencing the fastest growth. In general, there has been some convergence of GDHI per head towards the UK average, implying greater parity across regions in terms of household income.

Comparing these outcomes with the regional productivity performance in Figure 4 shows that, unlike income per head, productivity has been diverging from the UK average in most regions. Moreover, in terms of productivity, some regions have been performing close to the average while their income per head shows stronger divergences from average. The North East, for example, has had close to average but declining productivity since 2001 and at the same time the lowest, but improving, income per head. One reason for this might be the region's low employment and high unemployment rates (see labour market section).

Gross median weekly earnings represent another indicator of regional welfare.

Figure 6 shows the gross median weekly pay for all full-time employees, split into female and male workers, in each region in April 2008.

As in previous years, London was the region with the highest gross median weekly pay, at $£ 612.70$, followed by the South East, at $£ 499.80$. These were the only regions above the UK average of $£ 478.60$. Northern Ireland ( $£ 417.60)$, the North East ( $£ 420.60)$ and Wales ( $£ 421.00)$ recorded the lowest earnings in April 2008.

There were big differences between the weekly pay for male and female full-time employees across regions. The discrepancy was smallest in Northern Ireland, while it was largest in London and the South East. The weekly pay for male full-time employees was above the UK average for all full-time employees in nine of the 12 NUTS1 regions, while the weekly pay of female full-time employees was only above the UK average in London.

\section{Drivers of productivity}

HM Treasury and BERR have identified five key drivers of productivity - investment, innovation, enterprise, competition and 
skills - that can help explain differences in productivity across regions.

Alongside these five key drivers, other factors, such as connectivity, industrial structure and region-specific assets can have a strong influence on regional productivity.

\section{Investment}

Investment in physical capital, such as machinery, equipment and buildings, enables workers to produce more and higher quality output. Therefore, investment can have a significant positive impact on productivity. Due to quality concerns regarding the regional allocations of investment, which is recorded at the level of the enterprise and not at the local level, this article does not currently include data on investment.

Nevertheless, as Dunnell (2009) has pointed out, inflows of foreign direct investment (FDI) by region, measured by UK Trade \& Investment (UKTI), can serve as a narrow indicator of investment. However, FDI does not cover all investment in a region and there is no requirement to notify UKTI when undertaking FDI.

\section{Innovation}

Innovation is a necessary, although not sufficient, condition for economic success and is therefore recognised as an important driver of productivity. Innovation comprises, among others, the development of new technologies that increase efficiency and the introduction of new, more valuable goods and services. It also includes intangibles such as new methods of working and improvements to services.

$\mathrm{R} \& \mathrm{D}$ represents one of the determinants to the innovation process and is defined by the Organisation for Economic Cooperation and Development (OECD) in its Frascati Manual, which proposes a standard practice for surveys on $R \& D$, as 'creative work undertaken on a systematic basis in order to increase the stock of knowledge, including knowledge of man, culture and society, and the use of this stock of knowledge to create new applications'. The OECD definition of R\&D covers the following:

- basic research: experimental and theoretical work to obtain new knowledge of the underlying foundation of phenomena and observable facts, without any particular application or use in view

- applied research: work undertaken to acquire new knowledge, which is directed primarily towards a specific practical aim, and

- experimental development: systematic work, drawing on existing knowledge, which is directed at producing new materials, products or devices, installing new processes, systems and services, or at improving substantially those already produced or installed

The OECD definition excludes education, training and any other related scientific, technological, industrial, administrative or supporting activities. However, innovation depends on a wider set of inputs than R\&D, including skills training, design, software and organisational investment by firms. HM Treasury Economics Working Paper No. 1 quantifies these broader knowledge economy inputs at UK level; more work is needed before these factors can be measured effectively at regional level.

Figure 7 presents statistics on Business Expenditure on Research and Development (BERD), which are consistent with internationally agreed standards. New regional figures for 2007 were published on 30 January 2009. Figure 7 shows business expenditure on R\&D as a percentage of workplace-based GVA in 2001, 2003, 2005 and 2007. This is a measure commonly used in regional comparisons as it takes account of the size of regional economies.

The figure shows that, since 2001, the East of England has been the region with by far the highest $R \& D$ expenditure as a proportion of GVA, reaching 4.1 per cent in 2007. The South East had the second highest percentage ( 2.0 per cent), which has, however, been declining since 2001 .

$\mathrm{R} \& \mathrm{D}$ expenditure as a share of regional GVA was 1.8 per cent in the North West and 1.3 per cent in the East Midlands and the South West. London, Yorkshire and The Humber and the three Devolved Administrations of Wales, Scotland and Northern Ireland had the lowest shares in 2007, at around 0.5 per cent each. London's very low share of expenditure on $\mathrm{R} \& \mathrm{D}$ does not necessarily suggest low levels of innovation but might be due to it having a large concentration of service industries, which may be less $R \& D$ intensive (within the OECD definition) if, for example, they rely heavily on human capital.

\section{Enterprise}

Enterprise is defined as the seizing of new business opportunities by both start-ups and existing firms. New enterprises can bring innovative processes and technologies to market, forcing existing firms to improve their productivity in order to remain competitive.

The February 2009 REI article focused on business demography in UK regions, using the newly published ONS series of enterprise births and deaths, which includes enterprises registered for VAT and also those registered for pay-as-you-earn (PAYE). It needs to be noted that enterprise statistics relate to the place of registration of the enterprise, even though the enterprise may consist of more than one local unit, possibly in different regions.

Figure 8 shows the number of births and deaths of enterprises as a proportion of the active enterprise stock in 2007. The difference between the two represents the net change, which is calculated as a proportion of total stock. Figure 8 shows that the North East and Scotland had the highest rate of net change, at 4.8 per cent, closely followed by London, at 4.7 per cent. Wales and the South West had the lowest rates, at 1.6 and 2.3 per cent, respectively.

Figure 7

\section{Business expenditure on R\&D as a percentage of workplace-based GVA: by NUTS1 region}

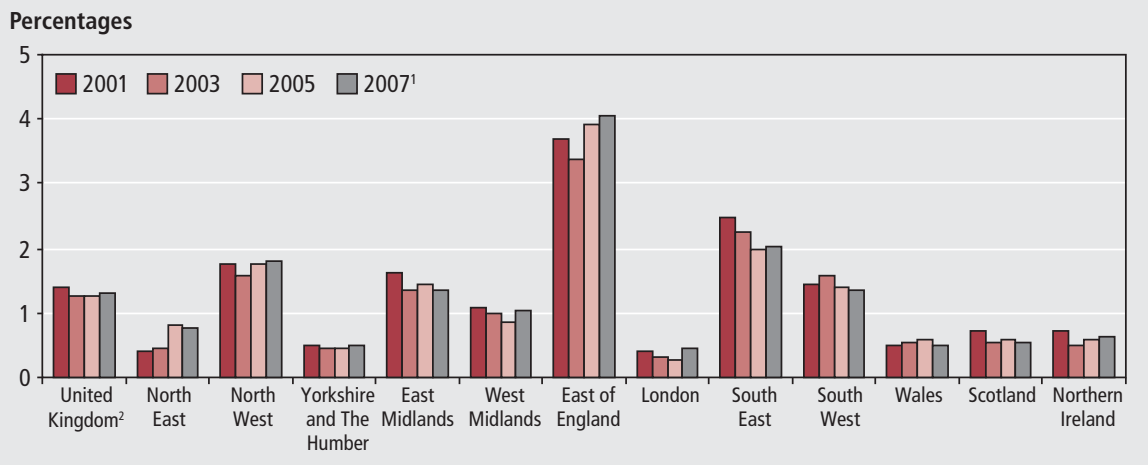

Notes:

1 Provisional.

2 UK less Extra-regio and statistical discrepancy.
Source: Regional Accounts and Business Expenditure on Research \& Development, Office for National Statistics 


\section{Figure 8 \\ Enterprise births, deaths ${ }^{1}$ and net change as a percentage of enterprise stock: by NUTS1 region, 2007}

\section{Percentages}

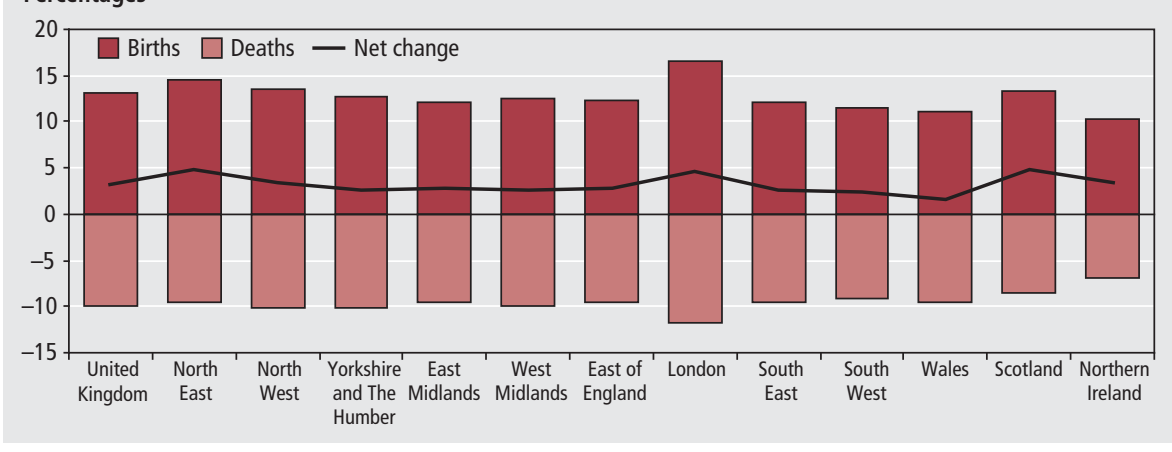

Note:

Source: Business Demography, Office for National Statistics

1 Provisional.

\section{Figure 9}

\section{Percentage of units surviving three years: by year of birth and NUTS1 region}

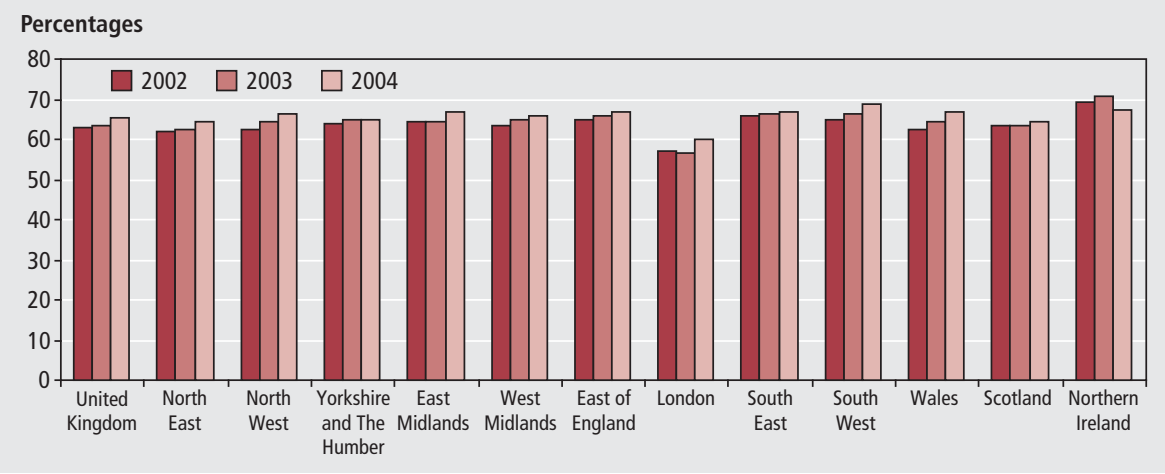

Source:Business Demography, Office for National Statistics

In 2007, across regions, the relatively modest net changes were the result of much greater proportions of enterprises joining and leaving the stock. These proportions were largest in London, followed by the North East. A relatively high proportion of enterprises joining and leaving the stock can be seen as desirable, as new enterprises entering the market are considered to bring innovative processes and technologies that drive up productivity and force unproductive enterprises to leave the market.

As well as analysing births and deaths of enterprises, it is useful to look at how long these enterprises survive. The Business Demography series contains data showing the number of years survived by enterprises born in the years 2002 to 2006 .

Figure 9 shows the proportion of enterprises born in 2002, 2003 and 2004 that survived for at least three years. In the UK as a whole, survival rates increased over the period, rising from 63 per cent of enterprises born in 2002 to 65 per cent of those born in 2004.

Patterns were similar across regions, with all but Northern Ireland having higher survival rates for enterprises born in 2004 than in 2002. Northern Ireland saw a fall from 69 to 67 per cent; however, this was still higher than the UK average of 65 per cent. Among enterprises born in 2004, those in the South West had the highest three year survival rate, at 69 per cent.

London stands out as the region with the lowest rate, at 60 per cent. Figure 8 has shown that London had the highest percentage of births and deaths of enterprises; therefore, it is not surprising that survival rates were relatively low. They could be an indication of London's ability to exploit short-term business opportunities. At the same time, it may suggest that many of the new enterprises born will not provide long-term growth and employment.

\section{Competition}

Vigorous competition enhances productivity by creating incentives to innovate and ensure that resources are allocated to the most efficient firms. It also forces existing firms to organise work more effectively through imitations of organisational structures and technology. One indicator of competition is the value of exports. Even though exports do not represent competition within a region, they still provide an indication of how international regions are in their outlook, and how able they are to face global competition.

HM Revenue \& Customs (HMRC) publishes statistics on regional trade in goods to the EU and non-EU destinations by statistical value. Trade in goods by definition excludes trade in intangibles and services. The statistical value of export trade is calculated as the value of the goods plus the cost of movement to the country's border.

Table 4 presents the latest estimates up to 2008 Q4, which include full-year figures for 2008. The total value of UK goods exports to all destinations increased by approximately 12 per cent between 2007 and 2008.

As the European Union (EU) is the main export destination for UK goods, the table separates exports to EU and non-EU destinations. In the UK as a whole, the value of exports to the EU grew by 10 per cent in 2008, with ten regions recording increases in exports. London and the North East reported the strongest rises, of 15 and 14 per cent, respectively. The East Midlands ( -3 per cent) and Scotland ( -1 per cent) were the only two regions that experienced declines in their exports to the EU in 2008.

In terms of the latest estimates (2008 Q4) compared with the previous quarter, the value of exports to the EU fell in all regions. Wales ( -21 per cent), and London ( -18 per cent) saw the strongest declines. These large falls may partly reflect the inherent volatility of quarterly trade data, although such declines are consistent with intensifying global financial and economic crises in the second half of 2008

UK exports to non-EU destinations grew by 16 per cent between 2007 and 2008, with the strongest increases recorded in the South East (31 per cent), Wales (28 per cent) and Northern Ireland (26 per cent). London (2 per cent) reported the smallest increase in its exports of goods to non-EU destinations in 2008.

Comparing estimates for 2008 Q4 with the previous quarter provides a rather mixed picture. In the UK as a whole, export values to non-EU destinations fell by 0.2 per cent. But this figure masks wide regional variation: half the regions experienced a decline compared with the previous quarter, while export values grew in the other half, with individual 
Table 4

UK regional trade in goods - statistical value of exports: ${ }^{1}$ by NUTS1 region

million

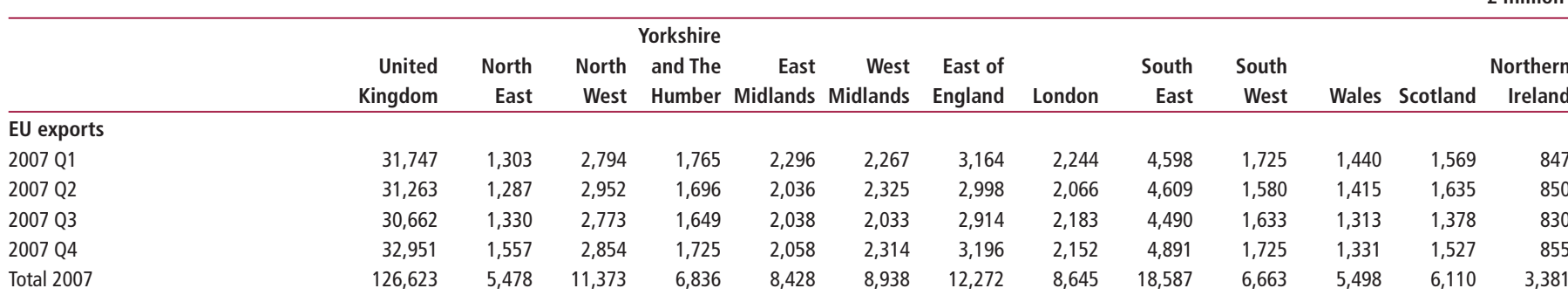

\begin{tabular}{|c|c|c|c|c|c|c|c|c|c|c|c|c|c|}
\hline $2008 Q^{2}$ & 34,971 & 1,636 & 3,176 & 1,746 & 2,194 & 2,404 & 3,301 & 2,303 & 4,924 & 1,826 & 1,519 & 1,492 & 880 \\
\hline $2008 \mathrm{Q2}^{2}$ & 36,976 & 1,629 & 3,305 & 1,879 & 2,118 & 2,506 & 3,579 & 2,424 & 5,334 & 1,926 & 1,655 & 1,490 & 970 \\
\hline $2008 Q^{2}{ }^{2}$ & 35,248 & 1,564 & 3,166 & 1,893 & 2,012 & 2,156 & 3,217 & 2,840 & 5,097 & 1,690 & 1,687 & 1,538 & 869 \\
\hline $2008 Q_{4}^{2}$ & 32,044 & 1,434 & 2,806 & 1,784 & 1,876 & 2,003 & 2,883 & 2,336 & 5,058 & 1,533 & 1,335 & 1,511 & 834 \\
\hline Total 2008 & 139,239 & 6,263 & 12,453 & 7,302 & 8,201 & 9,069 & 12,979 & 9,904 & 20,412 & 6,974 & 6,195 & 6,031 & 3,552 \\
\hline \multicolumn{14}{|c|}{ Non-EU exports } \\
\hline 2007 Q1 & 21,183 & 807 & 2,261 & 1,247 & 1,622 & 1,479 & 1,775 & 3,477 & 3,112 & 917 & 839 & 1,683 & 469 \\
\hline 2007 Q2 & 23,968 & 1,009 & 2,484 & 1,564 & 1,655 & 1,607 & 2,004 & 3,448 & 4,003 & 992 & 957 & 1,991 & 521 \\
\hline 2007 Q3 & 23,007 & 1,021 & 2,417 & 1,402 & 1,685 & 1,595 & 1,843 & 3,402 & 3,667 & 1,100 & 851 & 2,012 & 520 \\
\hline 2007 Q4 & 25,138 & 1,261 & 2,462 & 1,762 & 1,784 & 1,801 & 2,001 & 3,595 & 4,125 & 1,155 & 912 & 1,894 & 578 \\
\hline Total 2007 & 93,296 & 4,098 & 9,624 & 5,975 & 6,746 & 6,482 & 7,623 & 13,922 & 14,906 & 4,163 & 3,559 & 7,580 & 2,087 \\
\hline $2008 Q^{2}{ }^{2}$ & 23,867 & 1,164 & 2,452 & 1,641 & 1,743 & 1,767 & 2,167 & 3,195 & 3,892 & 1,053 & 869 & 1,833 & 555 \\
\hline $2008 Q_{2}^{2}$ & 27,792 & 1,335 & 2,862 & 1,712 & 1,940 & 1,990 & 2,509 & 3,661 & 4,993 & 1,178 & 1,074 & 2,066 & 639 \\
\hline $2008 Q^{2}$ & 28,257 & 1,357 & 2,936 & 1,707 & 1,914 & 2,142 & 2,268 & 3,577 & 5,173 & 1,373 & 1,312 & 2,103 & 623 \\
\hline $2008 Q^{2}$ & 28,194 & 1,112 & 2,806 & 1,522 & 2,087 & 1,902 & 2,277 & 3,749 & 5,443 & 1,306 & 1,298 & 2,227 & 806 \\
\hline Total 2008 & 108,110 & 4,969 & 11,056 & 6,582 & 7,683 & 7,801 & 9,220 & 14,181 & 19,501 & 4,910 & 4,553 & 8,229 & 2,622 \\
\hline
\end{tabular}

Notes:

Source: UK Regional Trade in Goods Statistics, HM Revenue \& Customs

1 Components may not sum to totals as a result of rounding.

2 Provisional.

performances ranging from a contraction of 18 per cent in the North East to an increase of 29 per cent in Northern Ireland. Again, falling export values are most likely the product of the ongoing recession.

Figure 10 shows the value of exports of goods as a percentage of workplacebased regional GVA in 2000 and 2007, which takes account of the differing sizes of regional economies. In 2007, exports from the North East accounted for the highest percentage of GVA (24 per cent), 6 percentage points above the UK average. The region where exports accounted for the smallest percentage of GVA in 2007 was London, at 9 per cent.

In terms of this indicator's change over time, in all regions, except Yorkshire and The Humber, exports accounted for a smaller percentage of GVA in 2007 than in 2000. Scotland experienced the most significant drop from 2000 to 2007, with exports in 2007 accounting for 16 percentage points less in terms of GVA than in 2000. Most other regions also experienced a decline from 2000 to 2004, with some recovery in 2005 and 2006. In 2007, most regions saw their exports as a percentage of GVA fall.
Skills

The skills of workers influence productivity as they define the capabilities that the labour force can contribute to the production process. The concept of skills includes attributes of the workforce, such as 'softer' or interpersonal skills, which are difficult to measure or to compare in different situations or over time. Therefore, qualifications are often used as proxy indicators. By examining the qualifications of the current workforce as well as those of young people, who represent the future capabilities of the labour market, a view of how skills are changing over time and their potential impact on productivity can be analysed.

The latest estimates of the highest qualifications (degree or equivalent) of the working-age population are based on 2008 Q4. ${ }^{1}$ However, as characteristics of local economies dictate which labour

\section{Figure 10 \\ Value of total export goods as a percentage of workplace-based GVA: by NUTS1 region}

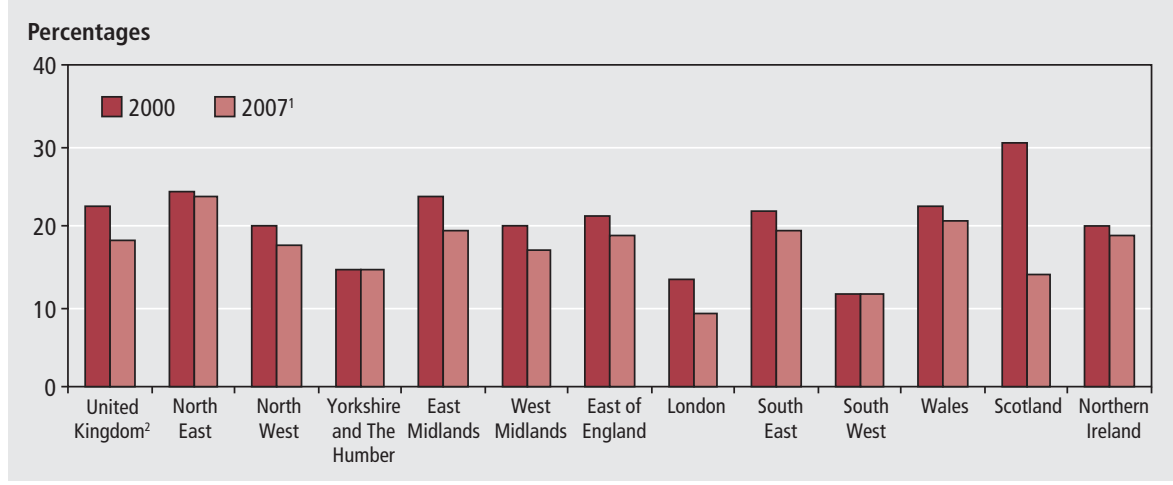

Notes:

1 Provisional.

2 UK less Extra-regio and statistical discrepancy.
Source: HM Revenue \& Customs, Regional Trade Statistics and Office for National Statistics 


\section{Figure 11 \\ Working-age population with no qualifications: ${ }^{1}$ by NUTS1 region, 2008 Q4}

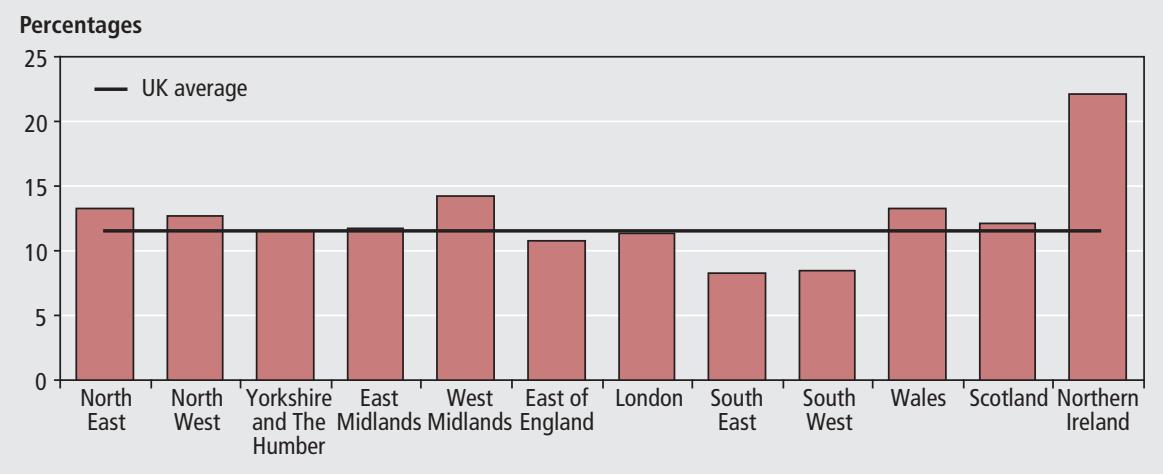

\section{Note:}

Source: Labour Force Survey, Office for National Statistics

1 For summary of qualifications and equivalents see

www.statistics.gov.uk/statbase/Product.asp?vlnk=836

\section{Figure 12 \\ Pupils achieving five or more grades $A^{*}$ to $C$ at GCSE level or equivalent in (i) all subjects and (ii) subjects including English and Mathematics: by NUTS1 region, 2007/08 ${ }^{1}$}

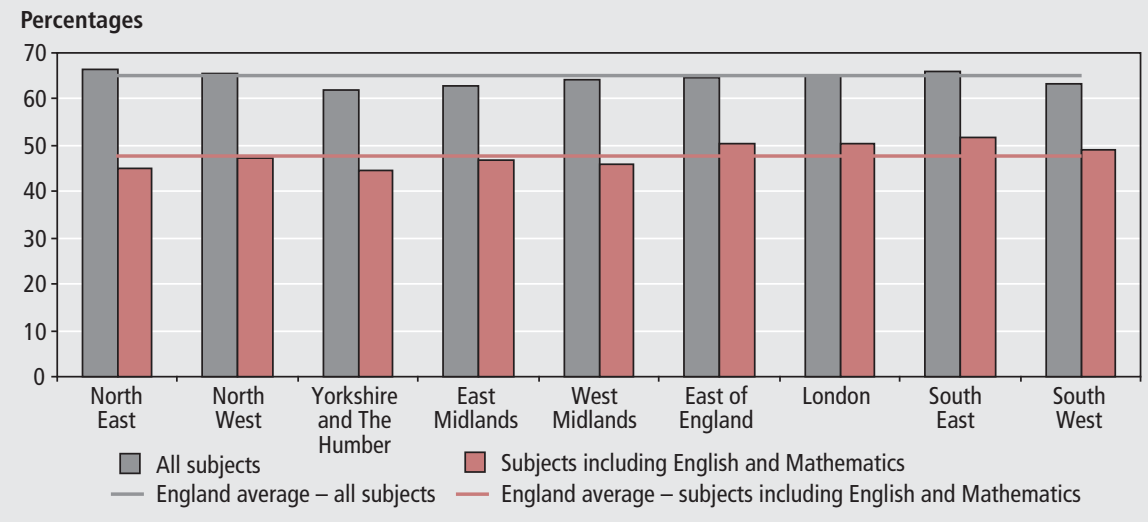

Note:

Source: Department for Children, Schools and Families

1 Revised data, includes attempts and achievements by these pupils in previous academic years.

2 The England average includes all schools, not only local authority maintained schools.

skills are required, comparability between regions might be difficult. An alternative approach is to compare the percentage of the working-age population that has no recognised qualifications.

Figure 11 shows the proportion of the working-age population that has no qualifications in each region, alongside the UK average, for 2008 Q4. Northern Ireland had the highest proportion of the population with no qualifications (10.4 percentage points above the UK average), whereas the South East and the South West had the lowest proportions, 3.4 and 3.2 percentage points below the UK average, respectively.

Above average proportions of workingage people without a qualification do not necessarily mean that regions have the most unqualified workforce. Due to differing regional skill requirements, people with recognised qualifications might migrate into other regions, where demand for their qualifications is high, while those without any recognised qualifications might migrate out of these other regions. Also, if employers have a strong demand for lower skills and a good supply of appropriate workers, a low skill equilibrium is created in a region.

Regional Skills Partnerships (RSPs) are groups brought together by Regional Development Agencies in each region of England in response to the National Skills Strategy. RSPs aim to strengthen regional structures to make skills provision more relevant to the needs of employers and individuals, covering private, public and voluntary sectors of the economy. They also aim to give regions the flexibility to tackle their own individual challenges and priorities.

Table 5 presents the RSP core indicators, which help to monitor the health of regional and local labour markets and progress towards national skills targets such as those documented in the Leitch Report. These core indicators will be supported by local, more specific, indicators identified by individual RSPs. The choice of ' 19 to state pension age' for some of the indicators in Table 5 has been influenced by: the increased emphasis on education and training after the age of 16 ; the plan to raise the standard school leaving age to 18 ; and alignment with indicators specified in the Local Area Agreements.

In order to assess the future capabilities of the labour force, the percentage of pupils achieving five or more grades $\mathrm{A}^{*}$ to $\mathrm{C}$ at GCSE level or equivalent in each English region can be used as an indicator. Recent focus on literacy and numeracy has led to a new measure being published, of five or more GCSEs grade $\mathrm{A}^{\star}$ to $\mathrm{C}$ in subjects including English and Mathematics. Figure 12 shows the percentage of pupils achieving at least five grades $\mathrm{A}^{*}$ to $\mathrm{C}$ at GCSE level or equivalent in any subjects, and in subjects including English and Mathematics.

In 2007/2008, the England average for all schools of pupils achieving five or more grades $A^{*}$ to $C$ in any subjects was 65 per cent, while it was down to 48 per cent if the subjects included English and Mathematics. Across all English regions, the percentage of pupils achieving at least five grades $A^{*}$ to $C$ in subjects including English and Mathematics was substantially lower compared with achieving the same in any subjects. Regional differences were more pronounced when subjects included English and Mathematics. In the North East and the North West, the percentage of pupils achieving five or more grades $\mathrm{A}^{*}$ to $\mathrm{C}$ in any subjects was above the England average, but these percentages dropped below the average when the subjects included English and Mathematics. The opposite holds for the South West, London and the East of England, where the proportion of pupils achieving at least five grades $A^{\star}$ to $C$ increased above the England average if the subjects included English and Mathematics.

\section{The labour market}

Table 6 shows the seasonally adjusted employment rate, the number of people of working age in employment, expressed as a proportion of the population, from the Labour Force Survey (LFS).

In quarter four (October to December) of 2008, the UK employment rate was 74.1 per cent, down 0.7 percentage points from a year ago and down 0.3 percentage points 
Table 5

Regional Skills Partnerships core indicators: by NUTS1 region

Percentages

\begin{tabular}{|c|c|c|c|c|c|c|c|c|c|c|c|}
\hline \multirow[b]{2}{*}{ Skills outcome indicators } & \multirow[b]{2}{*}{ Time period } & \multicolumn{5}{|c|}{ Yorkshire } & \multirow[b]{2}{*}{$\begin{array}{l}\text { East of } \\
\text { England }\end{array}$} & \multirow[b]{2}{*}{ London } & \multirow[b]{2}{*}{$\begin{array}{r}\text { South } \\
\text { East }\end{array}$} & \multirow[b]{2}{*}{$\begin{array}{r}\text { South } \\
\text { West }\end{array}$} & \multirow[b]{2}{*}{ England } \\
\hline & & $\begin{array}{r}\text { North } \\
\text { East }\end{array}$ & $\begin{array}{r}\text { North } \\
\text { West }\end{array}$ & $\begin{array}{l}\text { and The } \\
\text { Humber }\end{array}$ & $\begin{array}{r}\text { East } \\
\text { Midlands }\end{array}$ & $\begin{array}{r}\text { West } \\
\text { Midlands }\end{array}$ & & & & & \\
\hline $\begin{array}{l}\text { Percentage of employers with business or training plan, } \\
\text { or budget for training }\end{array}$ & 2007 & 70.6 & 69.2 & 69.6 & 67.9 & 67.5 & 67.3 & 70.0 & 70.6 & 68.4 & 69.1 \\
\hline Percentage of staff with skill gaps & 2007 & 6.3 & 5.3 & 4.8 & 6.8 & 5.4 & 7.8 & 6.7 & 5.8 & 6.2 & 6.1 \\
\hline $\begin{array}{l}\text { Skill shortage vacancies (SSVI) as percentage of all } \\
\text { vacancies }\end{array}$ & 2007 & 18.8 & 17.6 & 20.1 & 20.2 & 15.5 & 19.6 & 26.1 & 22.5 & 20.9 & 20.9 \\
\hline $\begin{array}{l}\text { Percentage of KS4 pupils achieving 5+ } A^{*} \text { to C GCSE } \\
\text { (inc Maths and English) }\end{array}$ & $2007 / 08$ & 44.9 & 47.4 & 44.4 & 47.0 & 46.1 & 50.3 & 50.6 & 51.7 & 49.2 & 47.6 \\
\hline Percentage of 19 year olds qualified to Level 2 or above ${ }^{1}$ & $2007 / 08$ & 75.9 & 74.3 & 73.2 & 73.1 & 74.9 & 77.0 & 77.0 & 79.6 & 77.0 & 76.7 \\
\hline Percentage of 19 year olds qualified to Level 3 or above ${ }^{1}$ & $2007 / 08$ & 43.7 & 46.1 & 44.4 & 46.0 & 46.9 & 52.4 & 51.9 & 56.9 & 51.0 & 49.8 \\
\hline Percentage of 19 to state pension age with Level $2+$ & Oct07 to Sept08 & 66.4 & 64.6 & 63.4 & 62.5 & 61.6 & 63.0 & 63.9 & 69.1 & 69.0 & 64.9 \\
\hline Percentage of 19 to state pension age with Level 3+ & Oct07 to Sept08 & 49.7 & 49.2 & 48.5 & 47.6 & 46.1 & 47.7 & 54.2 & 54.7 & 53.9 & 50.7 \\
\hline Percentage of 19 to state pension age with Level $4+$ & Oct07 to Sept08 & 25.3 & 27.6 & 26.7 & 26.7 & 26.2 & 27.8 & 40.2 & 33.5 & 30.5 & 30.5 \\
\hline $\begin{array}{l}\text { Percentage of } 19 \text { to state pension age with no } \\
\text { qualifications }\end{array}$ & Oct07 to Sept08 & 13.1 & 14.4 & 12.9 & 12.8 & 16.0 & 11.6 & 11.6 & 8.7 & 8.5 & 12.0 \\
\hline $\begin{array}{l}\text { Percentage of working-age population who undertook } \\
\text { job-related training in last } 13 \text { weeks }\end{array}$ & Oct07 - Sept08 & 30.0 & 26.1 & 26.4 & 26.5 & 26.5 & 24.2 & 26.0 & 27.2 & 28.8 & 26.6 \\
\hline $\begin{array}{l}\text { Percentage of } 17 \text { year olds in education or work-based } \\
\text { learning }\end{array}$ & end-2006 & 76.0 & 77.0 & 73.0 & 74.0 & 77.0 & 76.0 & 85.0 & 78.0 & 76.0 & 77.0 \\
\hline
\end{tabular}

Note:

1 Provisional data from DCSF matched datasets.
Source: Office for National Statistics; Labour Force Survey; Department of Business Enterprise and Regulatory Reform; Department for Children, Schools and Families; Department for Innovation Universities and Skills; National Employers Skills Survey 2007

Table 6

Employment ${ }^{1}$ rates for people of working age: by NUTS1 region

Percentages, seasonally adjusted

\begin{tabular}{|c|c|c|c|c|c|c|c|c|c|c|c|c|c|c|c|}
\hline & & & & & Yorkshire & & & & & & & & & & \\
\hline & & $\begin{array}{r}\text { United } \\
\text { Kingdom }\end{array}$ & $\begin{array}{r}\text { North } \\
\text { East }\end{array}$ & $\begin{array}{l}\text { North } \\
\text { West }\end{array}$ & $\begin{array}{l}\text { and The } \\
\text { Humber }\end{array}$ & $\begin{array}{r}\text { East } \\
\text { Midlands }\end{array}$ & $\begin{array}{r}\text { West } \\
\text { Midlands }\end{array}$ & $\begin{array}{l}\text { East of } \\
\text { England }\end{array}$ & London & $\begin{array}{r}\text { South } \\
\text { East }\end{array}$ & $\begin{array}{r}\text { South } \\
\text { West }\end{array}$ & England & Wales & Scotland & $\begin{array}{r}\text { Northern } \\
\text { Ireland }\end{array}$ \\
\hline 2005 & Oct-Dec & 74.4 & 70.1 & 72.8 & 74.2 & 77.2 & 73.4 & 77.6 & 69.4 & 78.7 & 77.7 & 74.6 & 71.9 & 75.3 & 69.0 \\
\hline 2006 & Jan-Mar & 74.7 & 71.3 & 73.5 & 74.4 & 77.0 & 73.9 & 77.3 & 69.9 & 78.9 & 78.3 & 75.0 & 71.6 & 75.1 & 69.4 \\
\hline & Apr-Jun & 74.6 & 71.6 & 73.2 & 74.2 & 77.0 & 73.9 & 77.0 & 69.7 & 78.9 & 78.6 & 74.9 & 71.3 & 74.7 & 69.9 \\
\hline & Jul-Sep & 74.6 & 71.0 & 73.6 & 73.5 & 77.0 & 73.9 & 77.2 & 69.8 & 78.8 & 77.9 & 74.8 & 72.0 & 75.5 & 69.3 \\
\hline & Oct-Dec & 74.5 & 70.9 & 72.8 & 73.7 & 76.5 & 73.0 & 77.0 & 70.0 & 78.7 & 78.2 & 74.6 & 71.8 & 76.2 & 69.9 \\
\hline 2007 & Jan-Mar & 74.3 & 71.0 & 72.5 & 72.8 & 75.9 & 72.5 & 77.3 & 70.1 & 78.2 & 78.0 & 74.4 & 71.7 & 76.6 & 70.6 \\
\hline & Apr-Jun & 74.5 & 71.4 & 72.6 & 73.3 & 76.0 & 72.7 & 77.4 & 69.7 & 78.5 & 78.1 & 74.5 & 72.1 & 77.0 & 70.6 \\
\hline & Jul-Sep & 74.6 & 72.1 & 72.4 & 73.4 & 75.7 & 73.0 & 77.2 & 70.7 & 78.8 & 78.6 & 74.7 & 71.3 & 76.6 & 70.1 \\
\hline & Oct-Dec & 74.8 & 71.6 & 72.8 & 73.7 & 75.8 & 73.3 & 78.1 & 70.4 & 78.9 & 79.3 & 75.0 & 71.6 & 76.6 & 69.9 \\
\hline 2008 & Jan-Mar & 74.8 & 70.2 & 72.4 & 74.0 & 76.2 & 73.2 & 77.7 & 71.1 & 79.5 & 79.0 & 75.0 & 72.0 & 76.5 & 69.7 \\
\hline & Apr-Jun & 74.7 & 70.2 & 72.2 & 73.4 & 75.7 & 72.5 & 77.7 & 71.5 & 79.4 & 78.8 & 74.8 & 72.6 & 76.5 & 70.1 \\
\hline & Jul-Sep & 74.4 & 70.4 & 71.6 & 73.2 & 76.1 & 71.8 & 77.4 & 71.0 & 79.0 & 78.7 & 74.5 & 70.6 & 76.3 & 70.1 \\
\hline & Oct-Dec & 74.1 & 70.1 & 71.0 & 72.3 & 76.2 & 71.8 & 77.5 & 71.6 & 78.7 & 78.1 & 74.3 & 70.7 & 75.4 & 68.8 \\
\hline
\end{tabular}

Note:

Source: Labour Force Survey, Office for National Statistics

1 Includes employees, self-employed, participants on government-supported training schemes and unpaid family workers.

from quarter three (July to September) of 2008. Regional rates varied from 78.7 per cent in the South East to 68.8 per cent in Northern Ireland.

Between the fourth quarters of 2007 and 2008 , the employment rate increased by 1.2 percentage points in London and by 0.4 percentage points in the East Midlands. The other ten regions experienced falls in their employment rates. These decreases were greatest in the North West (1.8 percentage points), the North East and the West Midlands, which both exhibited annual declines of 1.5 percentage points.

Table 7 shows the unemployment rate (according to the internationally-consistent International Labour Organisation definition) for persons aged 16 and over from the LFS. The UK rate in the fourth quarter of 2008 was 6.3 per cent, up 1.1 percentage points from a year ago and up 0.5 percentage points on the previous quarter. Regionally, the rates ranged from 8.4 per cent in the North East to 4.7 per cent in the South West.

Over the year the unemployment rate rose in all regions. The fastest increase, of 2.6 percentage points, occurred in the North East, while Wales, the North West and the West Midlands showed a rise of 1.9 percentage points. The smallest increase, of 0.2 percentage points, was recorded in Scotland.

Table 8 shows economic inactivity rates for persons of working age from the LFS. The UK rate in the fourth quarter of 2008 was 20.8 per cent, down 0.2 percentage points from the fourth quarter of 2007 and down 0.1 percentage points on the previous quarter. Across the regions, rates varied from 17.1 per cent in the South East to 27.4 per cent in Northern Ireland.

Compared with a year earlier, the performance of individual regions was mixed. The inactivity rate decreased in six regions, but grew in five and remained roughly the same in the West Midlands. The inactivity rate fell furthest in London, at 1.7 percentage points, while the largest annual rise, of 0.9 percentage points, occurred in Scotland. 
Table 7

Unemployment rates for people aged 16 and over: by NUTS1 region

Percentages, seasonally adjusted

\begin{tabular}{|c|c|c|c|c|c|c|c|c|c|c|c|c|c|c|c|}
\hline & & $\begin{array}{l}\text { United } \\
\text { Kingdom }\end{array}$ & $\begin{array}{r}\text { North } \\
\text { East }\end{array}$ & $\begin{array}{r}\text { North } \\
\text { West }\end{array}$ & $\begin{array}{l}\text { Yorkshire } \\
\text { and The } \\
\text { Humber }\end{array}$ & $\begin{array}{r}\text { East } \\
\text { Midlands }\end{array}$ & $\begin{array}{r}\text { West } \\
\text { Midlands }\end{array}$ & $\begin{array}{l}\text { East of } \\
\text { England }\end{array}$ & London & $\begin{array}{r}\text { South } \\
\text { East }\end{array}$ & $\begin{array}{r}\text { South } \\
\text { West }\end{array}$ & England & Wales & Scotland & $\begin{array}{r}\text { Northern } \\
\text { Ireland }\end{array}$ \\
\hline 2005 & Oct-Dec & 5.2 & 6.6 & 5.0 & 5.5 & 4.5 & 5.3 & 4.6 & 7.3 & 4.2 & 4.0 & 5.2 & 5.0 & 5.2 & 4.5 \\
\hline \multirow[t]{4}{*}{2006} & Jan-Mar & 5.2 & 6.5 & 4.9 & 5.4 & 5.0 & 5.3 & 4.9 & 7.6 & 4.5 & 3.6 & 5.3 & 4.8 & 5.3 & 4.3 \\
\hline & Apr-Jun & 5.5 & 6.1 & 5.3 & 5.8 & 5.5 & 5.6 & 5.0 & 7.8 & 4.7 & 3.8 & 5.5 & 5.6 & 5.5 & 4.3 \\
\hline & Jul-Sep & 5.5 & 6.7 & 5.5 & 6.0 & 5.3 & 6.1 & 4.8 & 7.8 & 4.5 & 3.8 & 5.6 & 5.4 & 5.0 & 4.7 \\
\hline & Oct-Dec & 5.5 & 6.7 & 5.4 & 6.0 & 5.7 & 6.7 & 4.5 & 7.7 & 4.3 & 3.9 & 5.6 & 5.3 & 5.2 & 4.2 \\
\hline \multirow[t]{4}{*}{2007} & Jan-Mar & 5.5 & 6.8 & 5.8 & 6.3 & 5.5 & 6.5 & 4.8 & 7.1 & 4.7 & 4.0 & 5.6 & 5.6 & 4.9 & 4.1 \\
\hline & Apr-Jun & 5.4 & 6.3 & 5.8 & 5.5 & 5.0 & 6.7 & 4.6 & 7.4 & 4.3 & 4.0 & 5.5 & 5.5 & 4.7 & 3.8 \\
\hline & Jul-Sep & 5.3 & 6.1 & 6.0 & 5.4 & 5.7 & 6.4 & 5.1 & 6.1 & 4.5 & 4.0 & 5.4 & 5.3 & 4.8 & 3.8 \\
\hline & Oct-Dec & 5.2 & 5.8 & 5.9 & 5.3 & 5.2 & 5.8 & 4.4 & 6.6 & 4.5 & 3.7 & 5.2 & 5.1 & 4.9 & 4.2 \\
\hline \multirow[t]{4}{*}{2008} & Jan-Mar & 5.2 & 6.5 & 6.0 & 5.0 & 5.5 & 6.2 & 4.5 & 6.9 & 3.9 & 3.7 & 5.3 & 5.4 & 4.6 & 4.6 \\
\hline & Apr-Jun & 5.4 & 7.5 & 6.3 & 6.1 & 5.7 & 6.3 & 4.6 & 6.9 & 4.2 & 3.8 & 5.6 & 4.9 & 4.2 & 4.2 \\
\hline & Jul-Sep & 5.8 & 8.0 & 6.8 & 6.8 & 5.9 & 6.5 & 4.8 & 7.4 & 4.6 & 4.2 & 6.0 & 6.7 & 4.7 & 4.1 \\
\hline & Oct-Dec & 6.3 & 8.4 & 7.8 & 6.6 & 6.1 & 7.7 & 5.5 & 7.2 & 4.9 & 4.7 & 6.4 & 7.0 & 5.1 & 5.1 \\
\hline
\end{tabular}

Source: Labour Force Survey, Office for National Statistics

Table 8

Economic inactivity rates for people of working age: by NUTS1 region

Percentages, seasonally adjusted

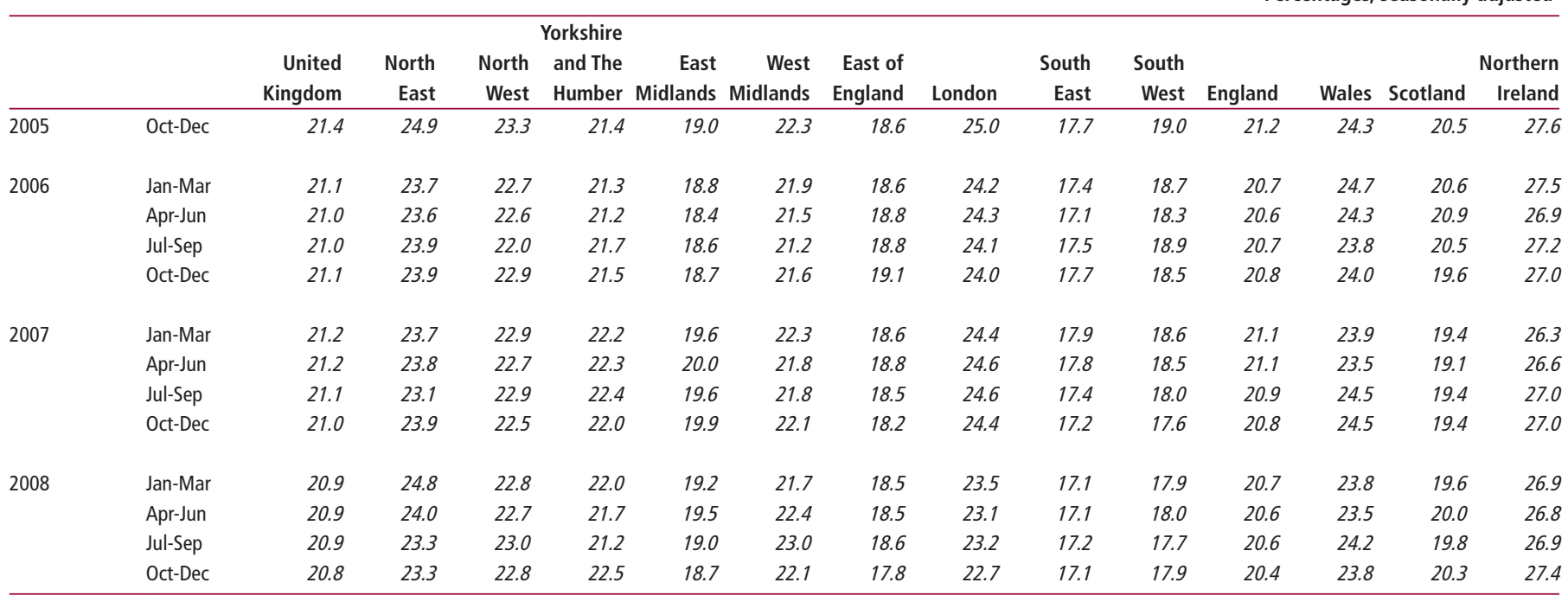

Source: Labour Force Survey, Office for National Statistics

Table 9

Employee jobs': by NUTS1 region

Thousands, not seasonally adjusted

\begin{tabular}{|c|c|c|c|c|c|c|c|c|c|c|c|c|c|c|}
\hline & & & & Yorkshire & & & & & & & & & & \\
\hline & $\begin{array}{r}\text { United } \\
\text { Kingdom }\end{array}$ & $\begin{array}{r}\text { North } \\
\text { East }\end{array}$ & $\begin{array}{r}\text { North } \\
\text { West }\end{array}$ & $\begin{array}{l}\text { and The } \\
\text { Humber }\end{array}$ & $\begin{array}{r}\text { East } \\
\text { Midlands }\end{array}$ & $\begin{array}{r}\text { West } \\
\text { Midlands }\end{array}$ & $\begin{array}{l}\text { East of } \\
\text { England }\end{array}$ & London & $\begin{array}{r}\text { South } \\
\text { East }\end{array}$ & $\begin{array}{r}\text { South } \\
\text { West }\end{array}$ & England & Wales & Scotland & $\begin{array}{r}\text { Northern } \\
\text { Ireland }\end{array}$ \\
\hline Dec 04 & 26,716 & 1,017 & 3,031 & 2,256 & 1,803 & 2,338 & 2,302 & 3,965 & 3,653 & 2,171 & 22,536 & 1,155 & 2,333 & 691 \\
\hline Dec 05 & 27,045 & 1,064 & 2,968 & 2,237 & 1,843 & 2,358 & 2,336 & 4,043 & 3,733 & 2,196 & 22,778 & 1,180 & 2,383 & 704 \\
\hline Dec 06 & 27,145 & 1,057 & 3,036 & 2,231 & 1,878 & 2,357 & 2,384 & 4,036 & 3,673 & 2,217 & 22,868 & 1,181 & 2,382 & 714 \\
\hline Dec 07 & 27,333 & 1,044 & 3,041 & 2,240 & 1,903 & 2,353 & 2,381 & 4,109 & 3,744 & 2,228 & 23,044 & 1,164 & 2,400 & 725 \\
\hline Mar 08 & 27,110 & 1,031 & 2,994 & 2,216 & 1,891 & 2,339 & 2,366 & 4,081 & 3,720 & 2,208 & 22,848 & 1,154 & 2,382 & 726 \\
\hline Jun 08 & 27,212 & 1,029 & 2,999 & 2,220 & 1,894 & 2,346 & 2,381 & 4,095 & 3,743 & 2,227 & 22,935 & 1,156 & 2,396 & 725 \\
\hline Sep $08^{2}$ & 27,117 & 1,030 & 2,996 & 2,208 & 1,883 & 2,326 & 2,387 & 4,074 & 3,732 & 2,237 & 22,862 & 1,152 & 2,387 & 716 \\
\hline Dec 08 & 27,015 & 1,036 & 2,988 & 2,187 & 1,876 & 2,319 & 2,379 & 4,066 & 3,713 & 2,210 & 22,774 & 1,145 & 2,385 & 711 \\
\hline
\end{tabular}

Notes:

Source: Employer surveys

1 Employee jobs figures are a measure of jobs rather than people. For example, if a person holds two jobs, each job will be counted in the employee jobs total. Employee jobs figures come from quarterly surveys of employers carried out by ONS and administrative sources.

2 Revised. 
Table 10

\section{Claimant count rates ${ }^{1}$ : by NUTS1 region}

Percentages, seasonally adjusted

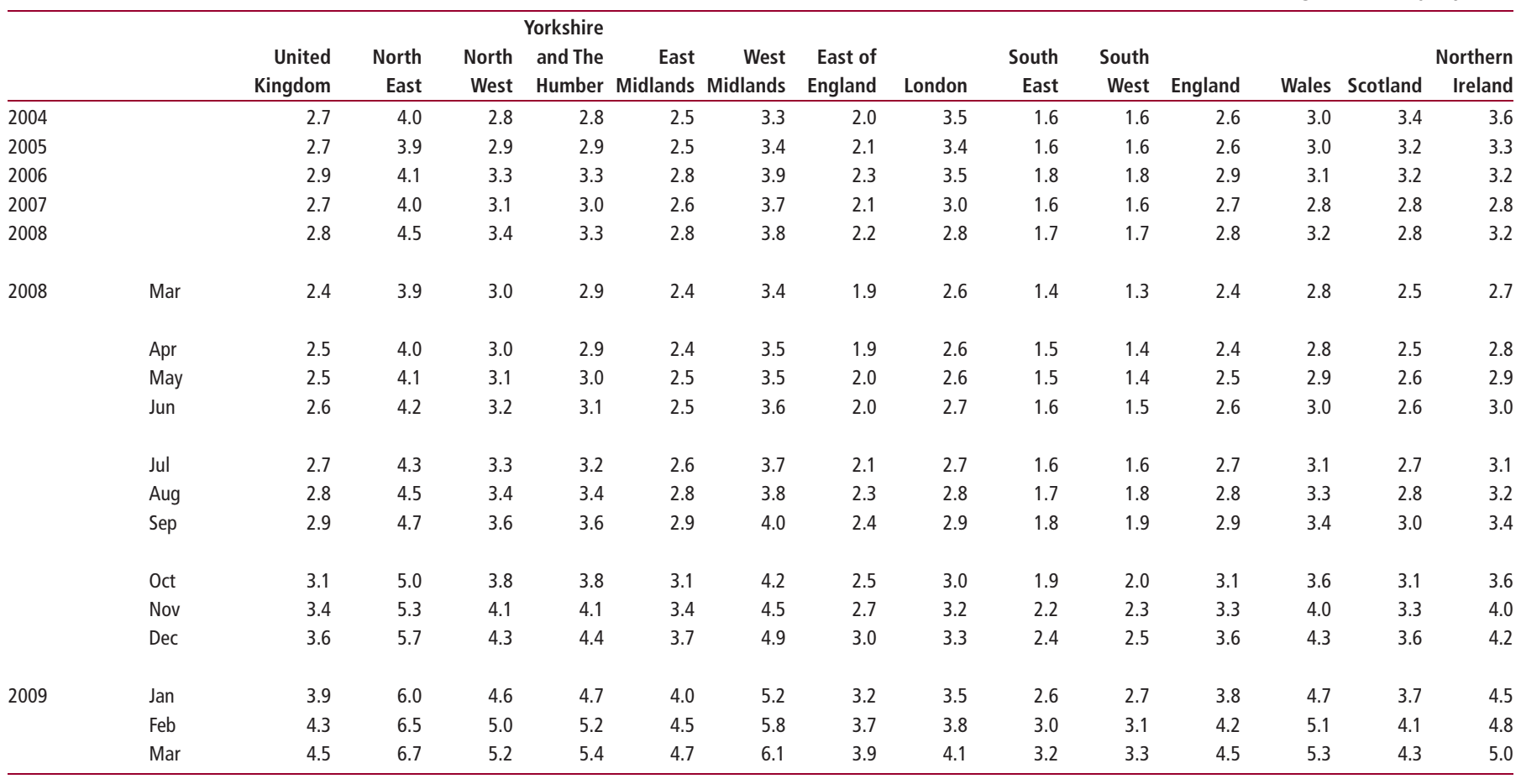

Note:

Source: Jobcentre Plus administrative system

1 Count of claimants of Jobseeker's Allowance expressed as a percentage of the total workforce - that is, workforce jobs plus claimants.

Table 9 shows the number of employee jobs, not seasonally adjusted, from the Employers Surveys. The number of UK employee jobs was 27 million, a decrease of 318,000 over the year since December 2007. In percentage terms, this was a 1.2 per cent decrease.

The number of employee jobs decreased in all twelve regions. The decline was largest in Yorkshire and The Humber (-2.4 per cent) and smallest in the East of England (-0.1 per cent).

Table 10 shows the claimant count rate (referring to people claiming Jobseeker's Allowance benefits as a proportion of the workforce). The UK rate was 4.5 per cent in March 2009, up 2.1 percentage points on a year earlier and 0.2 percentage points above the figure for February 2009. This national rate masks large variations between regions and component countries of the UK. The North East had the highest claimant count rate in the UK at 6.7 per cent, followed by the West Midlands (6.1 per cent), and Yorkshire and The Humber (5.4 per cent). The claimant count rate was lowest in the South East (3.2 per cent).

All regions exhibited an increase in the claimant count rate compared with a year ago. The largest increases were recorded in the North East (2.8 percentage points) and the West Midlands (2.7 percentage points), while London experienced the smallest increase, of 1.5 percentage points.

\section{Notes}

1 For a summary of all different levels of qualifications, see 'Notes and definitions' at www.statistics.gov.uk/statbase/product. asp?vlnk=836

\section{CONTACT}

凶 elmr@ons.gsi.gov.uk

\section{REFERENCES}

Department for Business, Enterprise \& Regulatory Reform (2007) Business Start Ups and Closures: VAT Registrations and Deregistrations in 2007 at

stats.berr.gov.uk/ed/vat/index.htm

Department for Children, Schools and Families (2008) GCSE and Equivalent Examination Results in England 2007/08

(Revised) Statistical First Release at www.dcsf.gov.uk/rsgateway/DB/SFR/ s000826/index.shtml

Department for Innovation, Universities and Skills (2006) Leitch Review of Skills at www.dcsf.gov.uk/furthereducation/index. $\mathrm{cfm}$ ?fuseaction $=$ content.view $\&$ Categoryl $\mathrm{D}=$ 21\&ContentID $=37$

Department for Innovation, Universities and Skills (2008) The Level of Highest Qualification Held by Adults: England 2007 Statistical First Release at
www.dcsf.gov.uk/rsgateway/DB/SFR/ s000777/index.shtml

Dey-Chowdhury S, Penny D, Walker M and Wosnitza B (2008) 'Regional Economic Indicators February 2008 with a focus on regional productivity' Economic \& Labour Market Review 2(2), pp 48-61 and at www.statistics.gov.uk/cci/article. asp? id =1945 Dunnell K (2009) 'National Statistician's article: measuring regional economic performance' Economic \& Labour Market Review 3(1), pp 18-30 and at www.statistics. gov.uk/cci/article. asp? $\mathrm{id}=2103$ Grierson and Allen (2008) 'Introducing the new business demography statistics' Economic \& Labour Market Review 2(12), pp 53-5 and at www.statistics.gov.uk/cci/article. asp? $\mathrm{id}=2096$

HM Revenue \& Customs Managed Service Companies at

www.hmrc.gov.uk/employment-status/msc.htm HM Revenue \& Customs (2009) UK Regional Trade Statistics Quarter 42008 at www.uktradeinfo.com/index.cfm?task=td_ regstats_press

HM Treasury (2004) Productivity in the UK 5: Benchmarking UK Productivity Performance. A Consultation on Productivity Indicators at www.hm-treasury.gov.uk/consult_ productivity_indicators_index.htm 
Holmes E (2008) 'Regional gross disposable household income' Economic \& Labour Market Review 2(8), pp 32-37 and at www. statistics.gov.uk/cci/article. asp? $\mathrm{id}=2031$

Office for National Statistics Annual Survey of Hours and Earnings at

www.statistics.gov.uk/statbase/product. asp?vInk=13101

Office for National Statistics Business Demography at www.statistics.gov.uk/statbase/product. asp?vlnk=15186

Office for National Statistics Business Expenditure on Research \& Development by Government Office Region at www.statistics.gov.uk/statbase/tsdataset. asp?vInk=572
Office for National Statistics Regional Household Income May 2008 Statistical First Release at

www.statistics.gov.uk/statbase/product. asp? vlnk=14651

Office for National Statistics Regional Trends 37: Notes and Definitions at

www.statistics.gov.uk/statbase/product. asp? vlnk=836

Office for National Statistics (2007) The ONS Productivity Handbook: A Statistical Overview and Guide at

www.ons.gov.uk/about-statistics/userguidance/productivity-handbook/ index.html

Wosnitza B and Walker M (2008) 'Regional Economic Indicators August 2008 with a focus on household income' Economic \& Labour Market Review 2(8), pp 49-60 and at www. statistics.gov.uk/cci/article. asp? $\mathrm{id}=2036$

Wosnitza B, Causer P and Knight J (2008) 'Regional Economic Indicators November 2008 with a focus on skills' Economic \& Labour Market Review 2(11), pp 44-57 and at www.statistics.gov.uk/cci/article. asp? id $=2069$

Organisation for Economic Co-operation and Development (2002) Frascati Manual: Proposed Standard Practice for Surveys on Research and Experimental Development Organisation for Economic Co-operation and Development (2003) 'Identifying the Determinants of Regional Performances' Working Party on Territorial Indicators 